\title{
Reduction of the Probability of Occurrence of Differential Pressure Sticking Through the Use of Diesel on Water Based Drilling Fluids
}

\author{
(Reducción de la Probabilidad de Ocurrencia \\ de Pega Diferencial Mediante el Uso de Diésel \\ en Fluidos de Perforación a Base de Agua),
}

\author{
David Almeida, ${ }^{1}$ Marco Loaiza, ${ }^{2}$ Raúl Valencia ${ }^{2}$
}

\begin{abstract}
The drilling campaign on Pad C of the Tiputini Field, located on the Oriente Basin, Ecuador, started with the first exploratory well TPTC-002. Pressure tests performed on the M1 sandstone of the Napo Formation determined that the average reservoir pressure (Pr) was 1921 psi. Ten months later, Pr averaged 846 psi. This increased the risk of differential pressure sticking, event that indeed occurred while drilling the well TPTC-016. By using the "Bow-Tie" methodology as a predictive tool to analyze risks, and taking into account the preliminary studies that describe this phenomena, a solution was found for stablishing an additional barrier with the use of diesel on the water-based drilling fluid. Diesel was used in order to extend the 'half value time' and to decrease the friction coefficient between the mud cake and pipe.
\end{abstract}

Keywords

Differential sticking; diesel; Bow-Tie; risk.

\section{Resumen}

La campaña de perforación en la plataforma C del campo Tiputini, localizado en la Cuenca Oriente, Ecuador, inició con un pozo exploratorio. Los puntos de presión de la Arenisca M1 de la formación Napo determinaron que la presión de reservorio (Pr) era de 1921 lpc en promedio. Diez meses después, la Pr se presentaba en valores cercanos a 846 lpc. Esto incrementó la probabilidad de ocurrencia de pega diferencial, evento que ocurrió en el pozo TPTC-016. Utilizando la metodología Corbata de Lazo, o "Bow-Tie" como una herramienta predictiva para analizar riesgos, y tomando en cuenta estudios preliminares que describieron el fenómeno, se encontró una solución estableciendo una barrera adicional a través del uso de diésel en el fluido de perforación a base de agua. El diésel se utilizó para entender el "tiempo de pega medio" y para disminuir el coeficiente de fricción entre la costra y la tubería.

\section{Palabras clave}

Pega diferencial; diésel; Laso Corbata; riesgo.

\section{Introduction}

On March 2016, drilling on a Tiputini Field at the Oriente Basin, Ecuador, started with the first exploratory well on Pad C. Pressure tests performed on the M1 Sandstone of the Napo Formation determined that the average reservoir pressure (Pr) was 1921 psi, which matched an equivalent density (ED) of $8.11 \mathrm{lbm} / \mathrm{gal}$ (Petroamazonas EP, 2016a).

By January 2017, Pr decreased considerably as shown on Table 1 (Petroamazonas EP, 2016b). 
Table 1. Reservoir pressure (Pr) of the M1 Sandstone

\begin{tabular}{|l|c|c|c|c|c|}
\hline \multicolumn{1}{|c|}{ Well } & $\mathbf{0 0 9}$ & $\mathbf{0 1 0}$ & $\mathbf{0 1 1 S 1}$ & $\mathbf{0 1 2}$ & 013 \\
\hline $\operatorname{Pr}(\mathrm{psi})$ & 846 & 873 & 835 & 877 & 820 \\
\hline ED (lbm/gal) & 3.55 & 3.65 & 3.45 & 3.73 & 3.46 \\
\hline
\end{tabular}

While drilling the well Tiputini C-016, a first event of differential pressure sticking occurred (differential pressure sticking occurs when the hydrostatic pressure is highly above $\mathrm{Pr}$ in a porous media, and this pressure differential pushes the pipe against the wall of the well, impeding movement); the pipe was liberated after two days, and after the hydrostatic column was reduced with the circulation of diesel in replace of the drilling mud. (Petroamazonas EP, 2016c).

To reduce this risk, drilling and tripping practices were modified as shown on Figure 1, locating it within the range of "undesirable" (Petroamazonas EP, 2016d).

Figure 1. Official risk evaluation matrix with the evaluation of differential pressure sticking risk

\begin{tabular}{|c|c|c|c|c|c|c|c|}
\hline \multirow{2}{*}{ RISK EVENT } & PROB & SEV & RISK & \multirow{2}{*}{ Preventive / Corrective Actions } & PROB & SEV & RISK \\
\hline & {$[1-5]$} & {$[1-5]$} & {$[1-25]$} & & {$[1-5]$} & [1-5] & [1 - 25] \\
\hline $\begin{array}{l}\text { Differential Pressure Sticking in front of } \\
\text { M1 Sandstone }\end{array}$ & 4 & 4 & 16 & $\begin{array}{l}\text { Keep movement of the BHA at all times.. Minimize comection time. Pull out BHA with back- } \\
\text { reaming in front of the sandstone. Calcium carbonate sealing of the sandstone. Keep mud } \\
\text { density under } 9.0 \mathrm{lbm} / \mathrm{gal} \text {. }\end{array}$ & 3 & 4 & 12 \\
\hline
\end{tabular}

Modifications were applied during the drilling operations on wells Tiputini C-017 and Tiputini C-018. However, an increase on tripping parameters while the Bottom Hole Assembly (BHA) was located in front of the M1 sandstone was experienced, especially on the "back-reaming torque", which increased up to 33 Klbf-foot (Petroamazonas EP, 2016d) and (Petroamazonas EP, 2016e). Also, horizontal displacement of the wells increased, and of course, inclination as well.

Lledó y Rivarola refer that in order to manage risk, a qualitative analysis defining the probability of occurrence and the magnitude of the impact must be made. From this qualitative analysis, a quantitative one, assigning numerical values to the probability of occurrence and its impact, can also be performed (Lledó y Rivarola, 2007). In case of differential pressure sticking, the impact of its occurrence is difficult to control, but the probability of its occurrence can be managed.

Standard risk analysis methods have the purpose of evaluating the probability or frequency of occurrence of the event, to decide if the risk is acceptable or not. One of the methodologies to identify risks is the use of "Bow-Tie" diagrams, used successfully on different situations and industries by De Dianous y Fiévez (2006), Khakzad (2012), Lewis y Smith (2010), and Shahriar, et al., (2012).

Every cause and consequence of an event is clearly defined by the "Bow-Tie" methodology. It is also a tool particularly adapted to represent the influences of the safety systems (barriers) and the evolution of occurrence scenarios for the events by (De Dianous y Fiévez, 2006).

According to Outmans (1958), the main causes that could lead to a differential pressure sticking scenario are: (i) big diameter drill collar or BHA, (ii) long BHA's, (iii) high hole deviations, (iv) high mud densities (if compared to the pore pressure), (v) high mud cake filtrate, (vi) high solids content of the mud, and (vii) pipe movement interruption. Outmans determined an equation to calculate the "half value time" $(T)$, which he defined as the sticking time required to let the sticking force increase to the fifty percent of its maximum value. 
Also, Annis y Monaghan (1962) laboratory studies demonstrated that an oil emulsion on a water-based drilling mud, densified with barite, reduces the friction coefficient be-tween steel and the mud cake. On the other hand, Holt y Falmy (1997) demonstrated that drilling with pure diesel reduces the probability of occurrence of differential sticking on horizontal holes.

On the Oriente Basin, there has not been an experience of the use of hydrocarbons to mitigate this problem, mainly due to environmental reasons. The situation has changed since cuttings re-injection processes were implemented. This research intends to contribute on designing a solution in the form of a control barrier, based on the phenomena understanding and the use of the "Bow-Tie" tool.

Although Outmans' theory of "Mechanics of Differential Pressure Sticking" is almost sixty years old, its application is still valid for explaining the phenomena. Based on Outman's conclusions, a solution will be reached.

As the problem has been stated, and previous studies to assess it were analyzed, the hypothesis of this research has been stated as follows: "The use of diesel on the drilling mud will constitute a barrier, which will enable the reduction of the probability of occurrence of differential pressure sticking on M1 sandstone, at Tiputini $C$ platform." Defined as it is, the general objective of this research is to prove the validity of the hypothesis.

\section{Methodology}

The methodology adopted a mixed approach (qualitative and quantitative), which implies the construction of diagrams and experimentation. A "Bow-Tie" diagram was built for identifying causes, control barriers and consequences of the critical event "differential pressure sticking". Once this was done, experimentation tests were performed at the laboratory and on site.

\section{1. "Bow-Tie" methodology}

"Bow-Tie" diagrams provide an easy understanding of the relationship among the causes, control barriers and mitigation measurements of an event (Lewis y Smith, 2010).

The first step to build a "Bow-Tie" diagram is the identification of the danger, the risk and the critical event, which is the objective of the analysis (De Dianous y Fiévez, 2006). In this case, the identified danger was "drilling through the low pressure M1 Sand-stone with a hydrostatic pressure highly above the pore pressure"; the risk associated to the danger is the "loose of tools and the well itself"; and the critical event, "the differential pressure sticking of the BHA".

Once the three aspects were identified, a list of causes and consequences for differential pressure sticking was made for this Field, using a "Bow-Tie" diagram as showed on Figure 2.

For each cause, a probability of occurrence can be assigned. For this study, the probabilities of occurrence were assigned to causes " $A$ ", " $B$ ", " $C$ " and " $D$ " respectively. The probabilities of occurrence include all the barriers, exception made to the diesel incorporation to the drilling mud. In this sense, the probability of occurrence of the critical event $(P)$ will initially be equal to the probability of occurrence of the causes " $\mathrm{A}$ " or " $\mathrm{B}$ " or " $\mathrm{C}$ " or " $\mathrm{D}$ ", expressed on Equation 1:

$$
\mathrm{P}=\mathrm{W}+\mathrm{X}+\mathrm{Y}+\mathrm{Z}
$$

Starting from here, an effective reduction of the probability of occurrence through the use of a new control barrier (in this case, the incorporation of diesel to the drilling mud) should 
be demonstrated with the calculation of a new probability of occurrence $\left(P^{\prime}\right)$ on Equation 2, so the hypothesis $\mathrm{P}^{\prime}<\mathrm{P}$ should be true.

$$
\mathrm{P}^{\prime}=\mathrm{W}^{\prime}+\mathrm{X}^{\prime}+\mathrm{Y}^{\prime}+\mathrm{Z}^{\prime}
$$

Figure 2. "Bow-Tie" diagram for the critical event

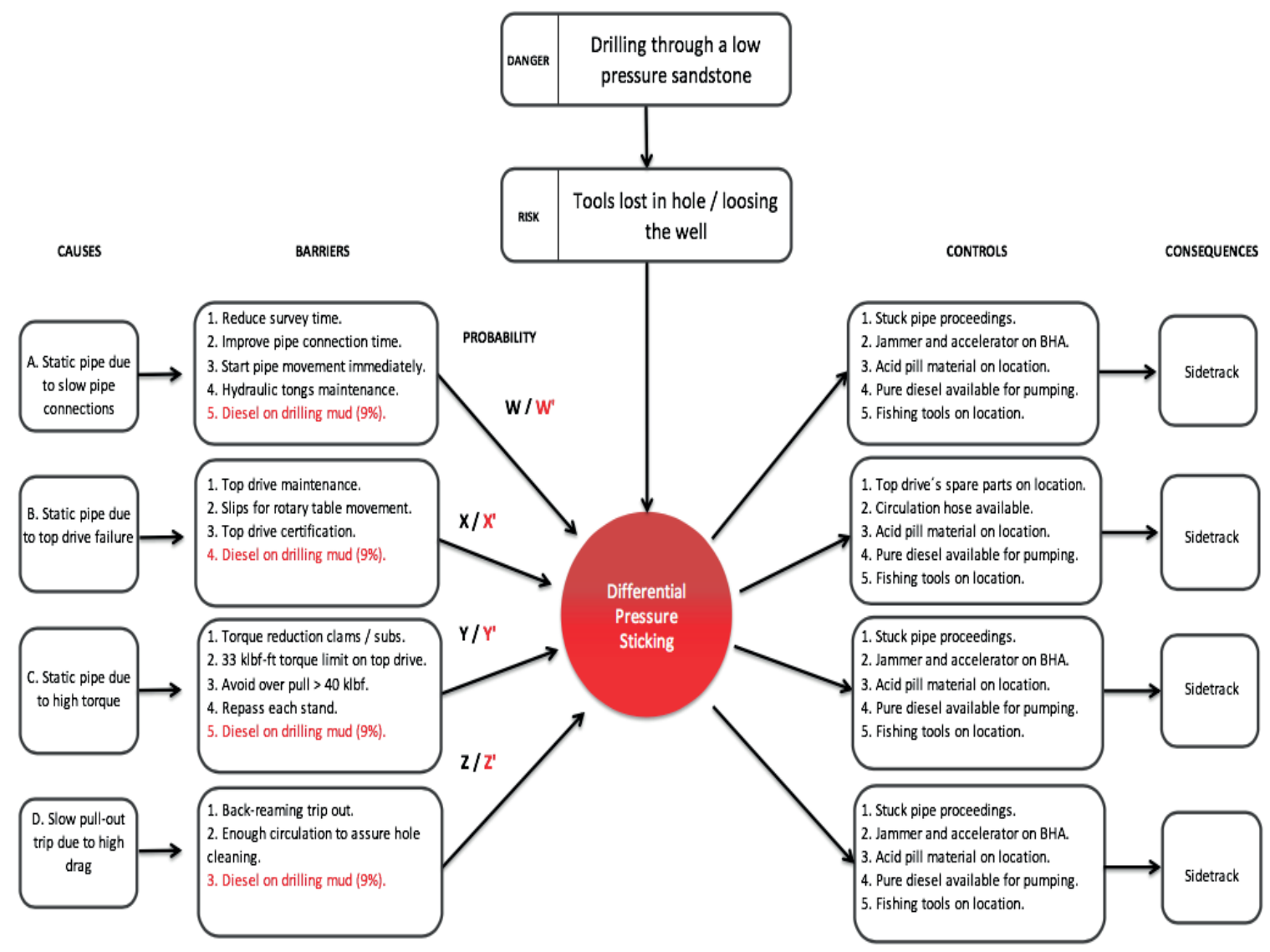

This hypothesis should only be true while experimental tests prove an effective reduction of the probability of occurrence for each cause. For this reason, laboratory and field testing were performed as part of the methodology detailed in the following sections.

\subsection{Laboratory and field testing}

Permeability Plugging Tests (PPT) were performed on drilling fluid samples with the same formulation and the addition of diesel on increments of $3 \%(v / v)$ for each test, under static conditions.

After laboratory testing was done, a diesel concentration was chosen to perform field testing while drilling the wells Tiputini C-028 and Tiputini C-030. At site, back-reaming torque and drag were measured and compared with the same measurements obtained on the well Tiputini C-018, under the same drilling mud formulation, but with cero diesel content. The drilling mud formulation is shown on Table 2. 
Table 2. Drilling mud formulation for testing (8.9 lbm/gal)

\begin{tabular}{|l|c|}
\hline \multicolumn{1}{|c|}{ Product } & Concentration (lbm/bbl) \\
\hline Clarified xanthan gum & 1.5 \\
\hline Starch - filtering controller & 6.5 \\
\hline Bactericide & 0.4 \\
\hline Clay inhibitor (quaternary amine) & 1.5 \\
\hline Calcium Carbonate 100 & 14.4 \\
\hline Calcium Carbonate 325 & 0.2 \\
\hline Calcium Carbonate 2 & 1.6 \\
\hline Calcium Carbonate 20 & 18.8 \\
\hline
\end{tabular}

\section{Results and Discussion}

Permeability Plugging Test (PPT): With the same formulation of drilling fluid shown on Table 2 , and incorporating diesel on increments of $3 \%$ from $6 \%$ to $24 \%$, a Permeability Plugging Test (PPT) was performed to each sample based on the API RP 13B-1 [14]. A differential pressure of $1,000 \mathrm{psi}$ and a temperature of $150^{\circ} \mathrm{F}$ were applied to the drilling mud on top of an aloxite disk of $850 \mathrm{mD}$ of permeability, trying to approach to the real drilling conditions of this field. Measurements of spurt loss (cm3) and total filtrate after $60 \mathrm{~min}$. (cm3) were obtained and tabulated, as shown on Table 3.

Table 3. Permeability Plugging Test (PPT) results

\begin{tabular}{|l|r|r|r|r|r|r|r|r|}
\hline \multicolumn{1}{|c|}{ Diesel (\%) } & \multicolumn{1}{c|}{$\boldsymbol{1}$} & \multicolumn{1}{c|}{$\boldsymbol{1}$} & \multicolumn{1}{c|}{$\mathbf{9}$} & \multicolumn{1}{c|}{$\mathbf{1 2}$} & \multicolumn{1}{c|}{$\mathbf{1 5}$} & \multicolumn{1}{c|}{$\mathbf{1 8}$} & \multicolumn{1}{c|}{$\mathbf{2 1}$} & \multicolumn{1}{c|}{$\mathbf{2 4}$} \\
\hline Density (lbm/gal) & 8.9 & 8.8 & 8.8 & 8.8 & 8.8 & 8.7 & 8.7 & 8.7 \\
\hline PV (cP) & 13 & 13 & 16 & 20 & 21 & 22 & 25 & 32 \\
\hline R6 & 19 & 21 & 20 & 26 & 22 & 22 & 22 & 23 \\
\hline R3 & 16 & 18 & 17 & 20 & 18 & 17 & 17 & 17 \\
\hline Spurt Loss $\left(\mathrm{cm}^{3}\right)$ & 3.2 & 1.6 & 1.6 & 1.6 & 1.6 & 1.6 & 1.6 & 1.6 \\
\hline API filtrate $\left(\mathrm{cm}^{3} / 30 \mathrm{~min}\right)$ & 5.4 & 4.3 & 3.8 & 3.4 & 3.1 & 2.5 & 2.4 & 2.1 \\
\hline Total filtrate $\left(\mathrm{cm}^{3}\right)$ & 14.0 & 10.2 & 9.2 & 8.4 & 7.8 & 6.6 & 6.4 & 5.8 \\
\hline
\end{tabular}

During testing, phase separation (water and diesel) was observed from a diesel concentration of $12 \%$ onwards. An emulsion was generated loosing stability of the mixture. Also from a concentration of $9 \%$ of diesel and forward, an important variation of the plastic viscosity was observed, while low RPM lectures (R3 and R6) maintained fairly constant.

According to the laboratory testing results, a concentration of $9 \%$ was selected for the field test. The specific gravity of the filtrate was also measured for diesel concentrations of 0 $\%$ and $9 \%$, to stablish if there was any important difference that could affect the half sticking time. Results are presented on Table 4.

Table 4. Specific gravity of mud filtrate

\begin{tabular}{|l|r|r|r|}
\hline \multicolumn{1}{|c|}{ Diesel (\%) } & 0 & 9 & \multicolumn{1}{c|}{ Variation } \\
\hline Specific gravity & 1.0431 & 1.0449 & $0.17 \%$ \\
\hline
\end{tabular}


Field testing: Two high angle wells were selected for field testing: (i) TPTC-028, and (ii) TPTC-030. Diesel was incorporated to the drilling mud, on a concentration of $9 \%$ before drilling operations of the $8 \frac{1}{2}$ in. section started. While tripping out, back-reaming torque and drag were plotted and compared with the same parameters recorded on TPTC-018, where the diesel concentration was $0 \%$. The main characteristics of the wells chosen are shown on Table 5. Drilling mud formulation on the three wells was the same, and corresponds to the one shown on Table 2.

Table 5. Characteristics of the wells chosen for field testing

\begin{tabular}{|l|c|c|c|}
\hline \multicolumn{1}{|c|}{ Well } & TPTC-018 & TPTC-028 & TPTC-030 \\
\hline Inclination (degrees) & 44 & 54 & 65 \\
\hline Section MD (ft) & 580 & 509 & 827 \\
\hline Risk zone height (ft) & 106 & 66 & 110 \\
\hline Diesel (\%) & 0 & 9 & 9 \\
\hline
\end{tabular}

\subsection{Results for dynamic conditions}

Outmans (1958) studied the distribution of forces on a mud cake exposed to differential pressure, under dynamic and static conditions of the drilling pipe. Therein he states that his conclusions are supported on the assumption that changes of the forces between the solid particles on the mud cake occur due to the change on water content.

For the case of mud flowing and pipe moving (rotating), Outmans estimated the forces behavior shown on Figure 3.

Figure 3. Variation of the "solid stress" and the hydraulic pressure through the mud cake height with drilling mud flow and pipe movement. Modified from Outmans

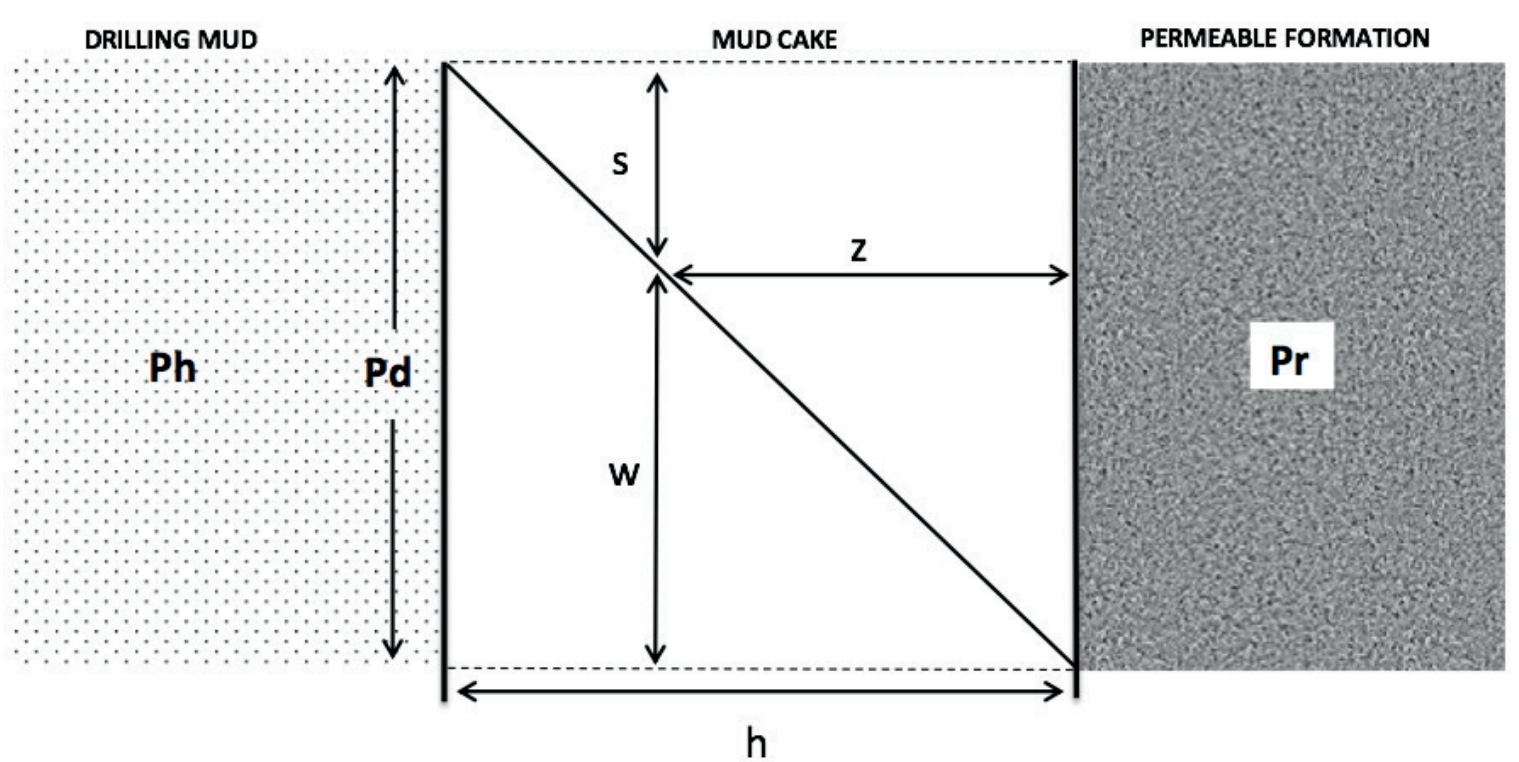

According to Outmans, the hydraulic differential pressure " $w$ " linearly declines through the mud cake of height " $\mathrm{h}$ ", from a value of "Pd" on the transition zone between the mud and the 
mud cake, to cero on the contact zone between the mud cake and the formation. The hydraulic pressure is the determined by Equation 3:

$$
\mathrm{w}=\left(\frac{\mathrm{Pd}}{\mathrm{h}}\right) z
$$

As the total differential pressure equals Pd (which is the difference between the hydrostatic pressure and the reservoir pressure), and only part of this pressure is transmitted by $W_{\text {, }}$ the solid stress " $s$ ", which equals Pd - w, must be transmitted from a solid particle to another as shown on Equation 4:

$$
\mathrm{s}=\mathrm{Pd}-\mathrm{w}=\left(\frac{\mathrm{Pd}}{\mathrm{h}}\right)(h-z)
$$

The main force which influences the friction factor increment due to differential pressure is the solid stress, and it grows as the hydraulic gradient diminishes through the mud cake height.

On the other hand, Ferguson y Klotz (1954) determined experimentally that, under dynamic conditions, the filtrate rate stabilizes after a determined circulation time, and the mud cake reaches an equilibrium state, on which its height does not variate, and its properties remain stable.

Therefore, under dynamic conditions friction coefficients are not affected by filtrate rate, and filtrate rate control is not important when viewed under differential pressure sticking considerations. It will not affect the probability of occurrence of the critical event.

However, field testing showed a change on the behavior of the trip-out parameters with the addition of diesel under dynamic conditions. Results of incorporating $9 \%$ of diesel to the drilling mud on the back-reaming torque, are presented on Figure 4. On Well TPTC-018, where no diesel was used, the trip out time was highly superior if compared with the time registered on wells TPTC-028 and TPTC-030, where a $9 \%$ of diesel was incorporated. Also, torque on TPTC-018 showed a very erratic behavior, with higher peaks and with a greater frequency of occurrence.

Figure 4. Back-reaming torque while the BHA was tripping out in front of the M1 Sandstone on the three wells studied

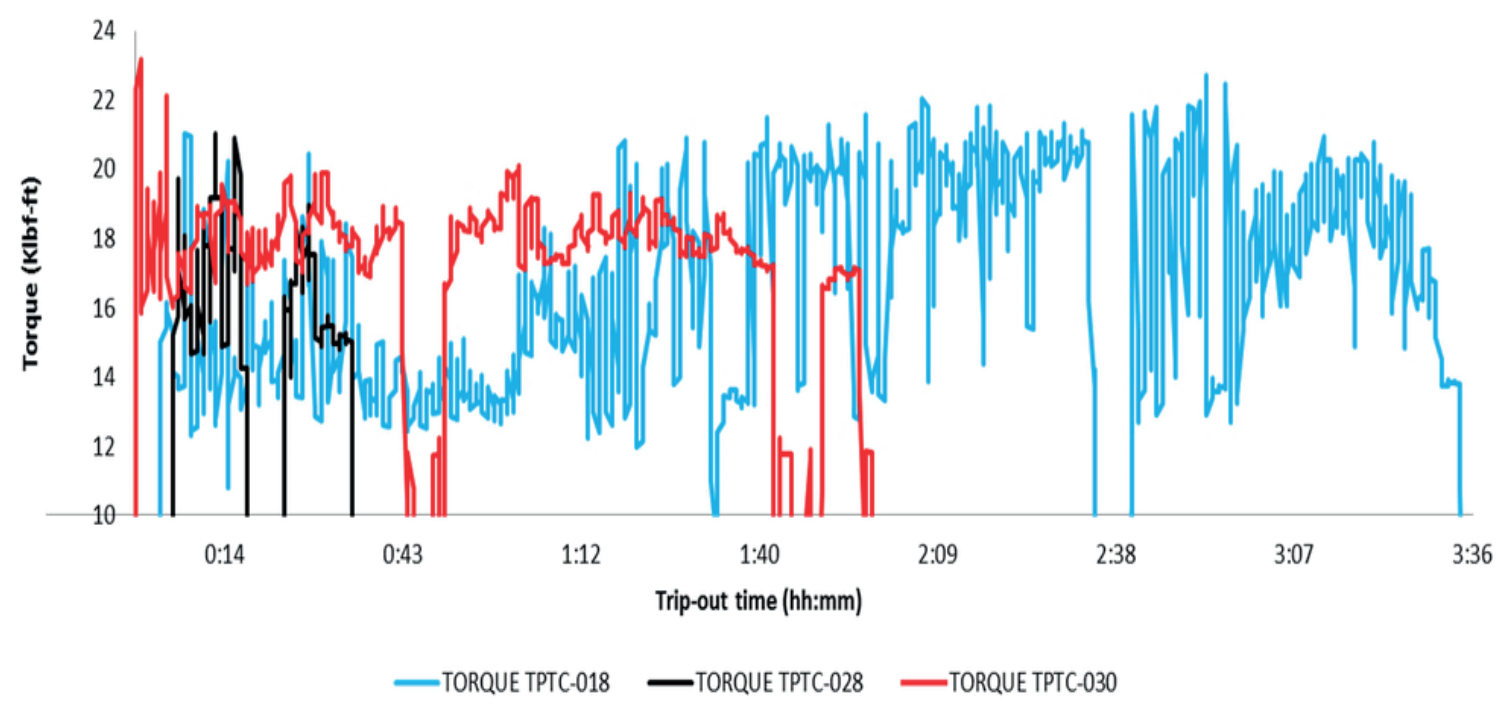


In addition, results in respect to the hook load (drag) on the same zones are presented on Figure 5. The plot showed that the hook load had an erratic behavior on well TPTC-018, while on TPTC-028 and TPTC-030, hook load was a lot more stable.

Figure 5. Back-reaming hook load while the BHA was tripping out in front of the M1 Sandstone on the three wells studied

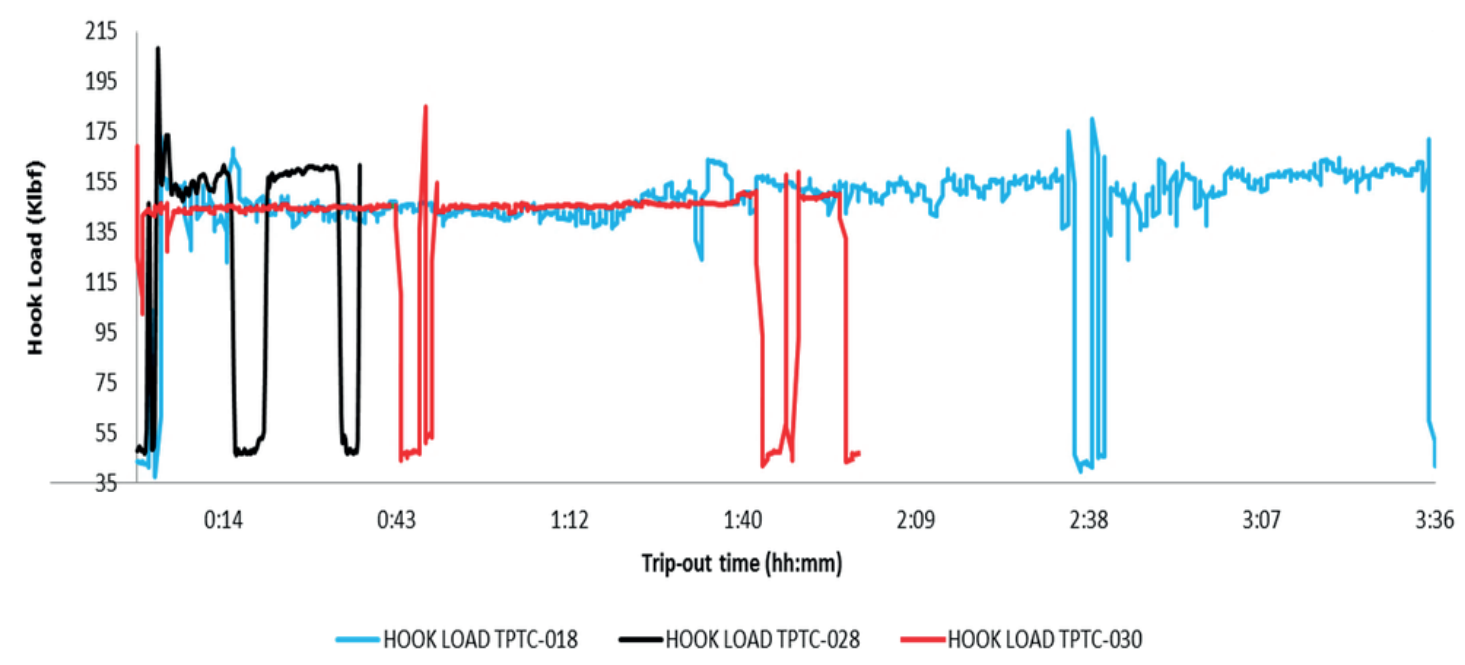

It is relevant to point out that wells TPTC-018 and TPTC-030 had a risk zone of similar height, and also TPTC-030 had a higher inclination, which implied that torque and drag on TPTC030 should have been higher with the same drilling mud properties. However, the addition of diesel proved to be effective on dynamic conditions, since it brought a more stable behavior of tripout parameters, reduced their magnitude and enabled a significant reduction on tripping time.

As it was mentioned before, since filtrate control should not be relevant under dynamic conditions, a different effect of diesel is responsible of this improvement on tripping out conditions, and it is that diesel lubricates the mud cake, reducing the friction coefficient on contact with the pipe.

\subsection{Results for static conditions}

According to Outmans, the opposite occurs when there is no mud flow and the pipe is static and in contact with the mud cake. Since the drilling mud has no chance to lubricate the mud cake, and it cannot penetrate the contact zone, the filtrate effect dehydrates the mud cake from a time "t0", and the solid stress increases until the hydraulic forces on the mud cake equals the reservoir pressure, so the solid stress equals the pressure differential at time "tn", increasing the friction factor, as presented on Figure 6. 
Figure 6. Variation of the solid stress and hydraulic pressure across the mud cake height under static conditions. Modified from Outmans

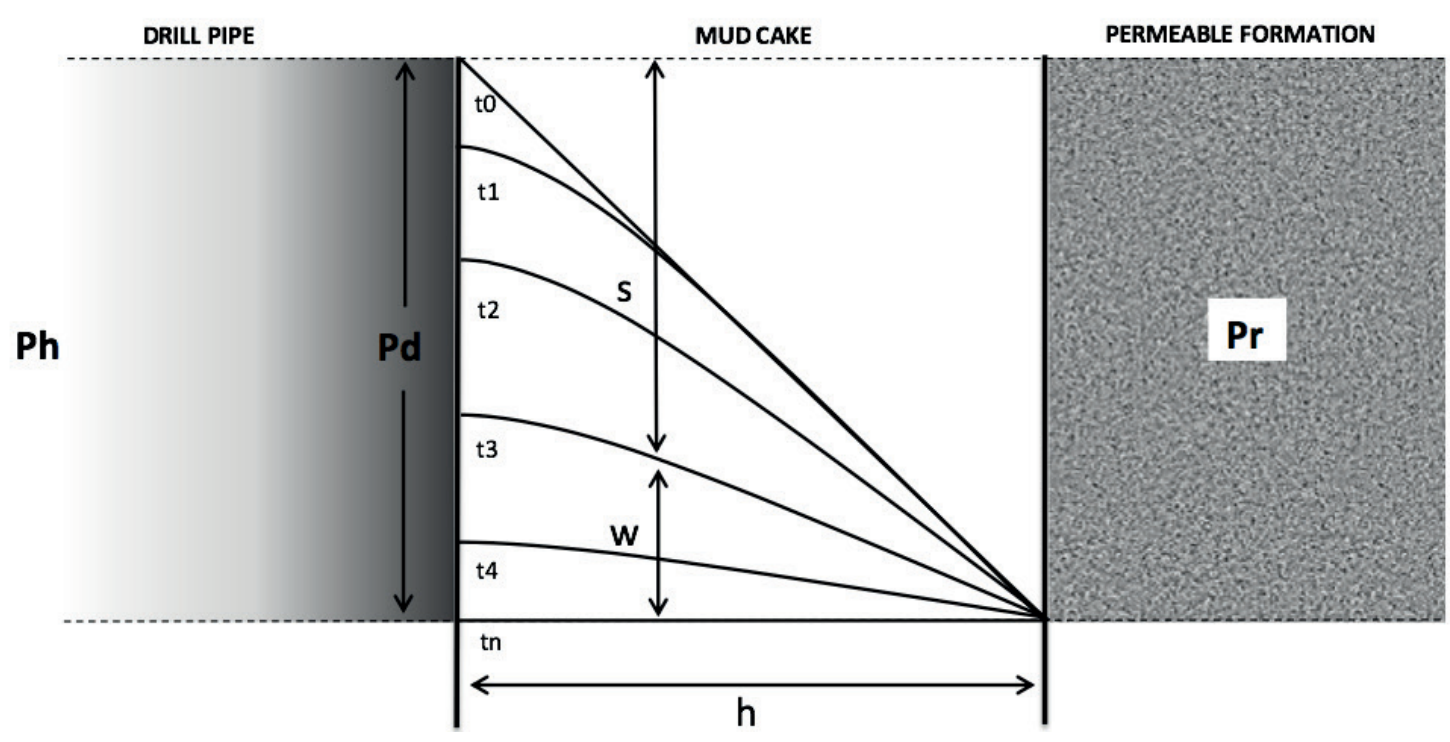

Outmans created Equation 5, that determines the half value time (T), which is the sticking time required to let the friction force increase to 50 percent of its maximum value. If we correlate Equation 5 with Darcy's Law expressed as Equation 6 (considering the mud cake as a homogenous porous media), we obtain Equation 7:

$$
\begin{gathered}
\mathrm{T}=\mu \cdot\left(\frac{\mathrm{d} \emptyset}{\mathrm{dP}}\right) \cdot\left(\frac{h^{2}}{6 \mathrm{k}}\right) \\
\mu=\gamma \cdot\left(\frac{\mathrm{dP}}{\mathrm{Q}}\right) \cdot\left(\frac{\mathrm{kA}}{\mathrm{h}}\right) \\
\mathrm{T}=\left(\frac{\text { Ahd }}{6}\right) \cdot\left(\frac{\mathrm{Y}}{\mathrm{Q}}\right)=\mathrm{C} \cdot\left(\frac{\mathrm{Y}}{\mathrm{Q}}\right)
\end{gathered}
$$

As the probability of occurrence will be analyzed for the same hole and mud conditions, with the only variation of the diesel content, (AhdØ/6) will be the same for both cases (with and without diesel), and can be called a constant C. So, the half value time will be affected directly by the specific gravity $(\mathrm{Y})$ and inversely affected by the filtrate rate $(\mathrm{Q})$. On the other hand, laboratory testing showed a very slight variation of $\mathrm{y}(0.17 \%)$ with a diesel concentration of $9 \%$, which is the reason it can be considered negligible.

According to this, it has been mathematically demonstrated that a decrement of the filtrate rate increases the half value time, making the differential pressure sticking slower.

With the results of the PPT testing, a parametric correlation was stablished between the diesel percentage and the total filtrate after 60 minutes, as presented on Figure 7. 
Figure 7. Parametric correlation, diesel fraction vs. Total Filtrate

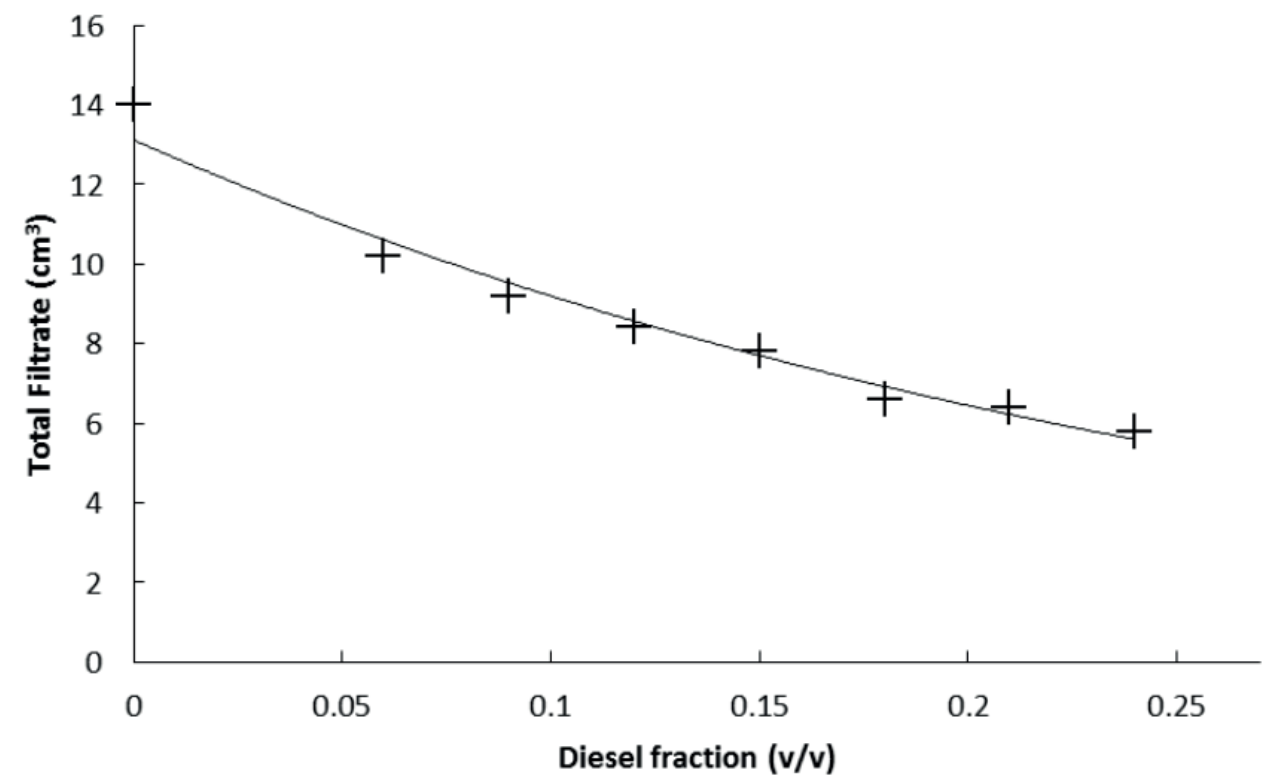

\subsection{New "Bow-Tie" diagram and hypothesis validation}

Referring back to the "Bow-Tie" diagram shown on Figure 2, we can state that the relationship between the probabilities of occurrence is:

$W^{\prime}<W$, because half value time is raised;

$X^{\prime}<X$, because half value time is raised;

$Y^{\prime}<Y$, because the mud cake friction coefficient is reduced;

$Z^{\prime}<Z$, because the mud cake friction coefficient is reduced.

According to these, the relationship between Equations 1 and 2 will be Inequalities 8 and 9:

$$
\begin{gathered}
\mathrm{W}^{\prime}+\mathrm{X}^{\prime}+\mathrm{Y}^{\prime}+\mathrm{Z}^{\prime}<\mathrm{W}+\mathrm{X}+\mathrm{Y}+\mathrm{Z} \\
\mathrm{P}^{\prime}<\mathrm{P}
\end{gathered}
$$

\section{Conclusions}

It was demonstrated, with the use of the methodology presented on this article, that the addition of diesel on a con-centration of $9 \%$ of the total volume of the drilling mud, helped to reduce the probability of occurrence of the critical event "differential pressure sticking", as it reduces the filtrate rate on the mud cake, increasing the half value time and reducing the friction coefficient of the mud cake. The hypothesis stated for this research was validated as true.

To extend the results of this research for application on other fields, a parametric correlation between the diesel fraction and the total filtrate can be stablished for different drilling mud formulations through laboratory testing. 
Further studies that involve a frequency of occurrence of events analysis, may enable quantitative demonstration of the magnitude of reduction of the probability of occurrence of the critical event, with the addition of diesel.

Finally, further studies should also enable the analysis of the feasibility of the use of emulsion control products, that may allow to increase the diesel concentration on the water based drilling mud over the $12 \%$, to maximize the reduction of filtrate rate and to control rheological properties.

\section{Nomenclature}

$\begin{array}{ll}\text { W } & \text { hydraulic differential pressure } \\ \mathrm{Ph} & \text { hydrostatic pressure } \\ \mathrm{Pr} & \text { reservoir pore pressure } \\ (\mathrm{d} \varnothing / \mathrm{dP}) & \text { coefficient of consolidation } \\ \mathrm{h} & \text { mud cake height, } \\ \mathrm{k} & \text { intrinsic permeability } \\ \mu & \text { mud filtrate viscosity } \\ \mathrm{V} & \text { specific gravity of the mud filtrate } \\ \mathrm{Q} & \text { mud filtrate rate. } \\ \mathrm{d} & \text { diesel fraction on the drilling mud } \\ \mathrm{A} & \text { Porous area }\end{array}$

\section{References}

Annis, M. R., y Monaghan, P. H. (1962). Differential Pressure Sticking-Laboratory Studies of Friction Between Steel and Mud Filter Cake. Society of Petroleum Engineers. doi:10.2118/151-PA.

API RP 13B-1. (2009). Recommended Practice for Field Testing Water-based Drilling Fluids. 4th Edition. API.

De Dianous, V., y Fiévez, C. (2006). ARAMIS project: A more explicit demonstration of risk control through the use of bow-tie diagrams and the evaluation of safety barrier performance. Journal of $\mathrm{Ha}$ zardous Materials, 130 (3), 220-233.

Ferguson, C. K., y Klotz, J. A. (1954, February 1). Filtration From Mud During Drilling. Society of Petroleum Engineers. doi:10.2118/289-G

Holt, C. A., y Falmy, H. (1997). The Successful Application of Diesel as Horizontal Drilling Fluid. Society of Petroleum Engineers. doi:10.2118/39283-MS

Khakzad, N., Khan, F., y Amyotte, P. (2012). Dynamic risk analysis using bow-tie approach. Reliability Engineering y System Safety, 104, 36-44.

Lewis, S., y Smith, K. (2010). Lessons learned from real world application of the bow-tie method. In Prepared for Presentation at American Institute of Chemical Engineers-6th Global Congress on Process Safety San Antonio.

Lledó, P., y Rivarola, G. (2007). Gestión de proyectos. Pearson Educación.

Outmans, H. D. (1958). Mechanics of Differential Pressure Sticking of Drill Collars. Society of Petroleum Engineers.

Petroamazonas EP, (2016a). Plan de Desarrollo Bloque 43-Ishpingo, Tiputini, Tambococha-ITT, unpublished, Petroamazonas EP, Ecuador.

Petroamazonas EP, (2016b). Presión de reservorio M1 en la plataforma Tiputini C [database], unpublished, Petroamazonas EP, Ecuador.

Petroamazonas EP, (2016c). Reporte final de Perforación- Pozo Tiputini C-016, unpublished, Petroamazonas EP, Ecuador. 
Petroamazonas EP, (2016d). Programa de Perforación- Pozo Tiputini C-017, unpublished, Petroamazonas $E P$, Ecuador.

Petroamazonas EP, (2016e). Reporte final de Perforación- Pozo Tiputini C-018, unpublished, Petroamazonas EP, Ecuador.

Shahriar, A., Sadiq, R., y Tesfamariam, S. (2012). Risk analysis for oil \& gas pipelines: A sustainability assessment approach using fuzzy based bow-tie analysis. Journal of Loss Prevention in the Process Industries, 25 (3), 505-523. 